Joanna Gocłowska-Bolek

Center for Political Analysis

University of Warsaw, Warsaw, Poland

(D) https:/ / orcid.org/0000-0001-7587-5416

\title{
Strengthening Polish-Mexican Academic Cooperation: Present and Future Perspectives
}

\begin{abstract}
Science and higher education have always been intensely internationalized areas of human activity. Especially in the era of globalization, higher education systems around the world face the challenge of internationalization. Internationalization not only strengthens opportunities for development, but is seen as an inevitable necessity in the globalizing and strongly competitive world. Although there is a long-standing tradition of academic cooperation between Poland and Mexico, the changing reality enforces increased efforts to build a more conscious, comprehensive relationship with measurable, long-lasting results. Since ad hoc contacts between individual researchers are not sufficient any longer, a complex, realistic vision of such cooperation is needed. Universities in Poland and Mexico start to see the opportunity to intensify cooperation, which - effectively explored - can significantly contribute to a nation's economic competitiveness in general and to understanding the nature of trends and challenges in international higher education. The author discusses current activities within the framework of academic cooperation between the two countries and the most important initiatives that may bring closer cooperation in the future. A special focus will be put on the challenges faced by both countries in higher education cooperation schemes, as seen from the Polish perspective.
\end{abstract}

Keywords: Poland, Mexico, internationalization, higher education, academic cooperation, scientific cooperation

\section{Introduction}

There are a variety of ways to define and describe internationalization. Knight (Internationalization... 3) states that the internationalization of higher education is "the process of integrating an international, intercultural, or global dimension into the purpose, functions or delivery of postsecondary education", which in practice means "the process of commercializing research and postsecondary education, and international competition for the recruitment of foreign students from wealthy and 
privileged countries in order to generate revenue, secure the national profile, and build an international reputation". Internationalization includes the policies and practices undertaken by academic systems and institutions - and individuals - to cope with the global academic environment (Knight, Updating...). The motivations for internationalization include: commercial advantage, knowledge and language acquisition, enhancing the curriculum with international content, and many others. Specific initiatives such as: branch campuses, cross-border collaborative arrangements, programs for international students, establishing English-medium programs and degrees, summer schools, and others can be put into place as part of internationalization (Altbach, Knight 291). In this sense, the main components of internationalization of higher education are: global competition for talents, the recruitment of international students, the development of international branch campuses, students, staff and a scholars exchange programs, internationalization of the curriculum, and research and education partnerships between institutions regionally and internationally (Khorsandi Taskoh 10), but the list is still open for new initiatives.

There are specific rationales which drive the internationalization of higher education institutions (HEIs). Zha Qiang (248-249) argues that there are several reasons widely served as main driving forces for internationalization. First of all, higher education is expected to provide an adequate response to the demands of the globalization of societies, economies, labor markets, consumer expectations, etc. This expectation is reflected in academic and professional requirements, but also in: multilingualism, social and intercultural skills and attitudes, openness to international cooperation. On the other hand, the growing level of specialization in research and the demand for indispensable financial investments in $\mathrm{R} \& \mathrm{D}$ require collaborative efforts and intensive international cooperation. It is worth emphasizing that the requirement of foreign students has become a significant factor for institutional income and, as such, of national economic interest. And the growing capability to use of new information and communication technologies (ICT) in the delivery of education and research cooperation, falling travel costs, an increase in knowledge about other parts of the world, the involvement of private actors result in the national governments having to take the priority of internationalization into consideration while creating a higher education and science policy. The internationalization of higher education is thus seen as one of the ways in which countries respond to the challenges of globalization, yet respecting the individuality of nations (national identity, culture, unique history, resources, priorities etc.) (Qiang 249).

In the contemporary approach it is commonly indicated that the internationalization of higher education is not an aim itself. It is rather seen as a means to achieve a wider goal, e.g. quality improvement, restructuring, upgrading of higher education systems and services (Van der Wende 5). Some authors (Johnston, and Edelstein, and followers) state that the dominant argument for internationalizing higher education is ensuring a nation's economic competitiveness. Knight and De Wit (1999) and Blumenthal (1996) discern the political and economic rationales, including arguments related to economic growth and investment in the future economy, the labor market, foreign policy, financial incentives and national educational demand, as well as educational and cultural rationales, including the development of the individual, the international dimension to research and teaching, institution building, quality improvement, and statements of the cultural functions. 
All these arguments may be useful while building strategies of higher education internationalization in the cases of Poland and Mexico and while finding rationales for strengthening their academic cooperation. The author will examine the current most important activities within the framework of academic cooperation between the countries and initiatives that may bring closer cooperation in the near future. A special focus will be put on the challenges faced by both countries in higher education cooperation schemes, as seen from the Polish perspective.

\section{Mexico as a partner in the internationalization of Polish higher education}

Mexico is an important country both at the regional and world level. It comes second in Latin America by the size of its population (124 million in 2017, compared to 208 million for Brazil, 17.8 for Chile, and 38.5 for Poland) which keeps growing - more slowly than in previous decades - at about $1.2 \%$ annually. In 2017 , the median age of the Mexican population was 28 years - compared to 41 years in Poland. Mexico is a full member of the OECD (together only with Chile in Latin America). With a GDP per capita of over USD 20,082 in 2017 (in purchasing power parity, ppp), it was at the level with Chile $(25,425)$, Uruguay $(23,504)$ and Argentina $(21,370)$ and ahead of all other countries in the region, including Brazil $(15,919)$; although still significantly lower than Poland $(30,827)$. Its GDP increased at a rate of $2.2 \%$ (the Latin American average was 1.1\%) in 2017, while Poland's rate of growth was 4.6\% (OECD Science, 2017).

Mexico is one of the most important, after Brazil, Polish trading and investment partners in Latin America. In 2015, trade turnover between the countries exceeded USD 1 billion. $0.26 \%$ of all Polish exports are sent to Mexico and this share is steadily growing. The growing interest of Polish business in the Mexican market and the growing involvement of Mexican companies in Poland draws attention. In 2016, Mexico - as the only country in the region, was posted by the Polish Ministry of Development on the list of prospective markets for Polish economic cooperation. ${ }^{1}$

There is a large share of the top universities in Latin America in Mexico. During the 20th and the 21st centuries, Mexico has made significant progress in science, technology, and innovation (Gocłowska-Bolek, Fostering Economic... 203). The National Autonomous University of Mexico (Universidad Nacional Autónoma de México, UNAM) consistently ranks among the world's best universities. Its main campus is itself a UNESCO heritage site, crammed with sculptures and murals. The Monterrey Institute of Technology and Higher Education (Tecnológico de Monterrey) is one of the most prestigious technical institutions in the world, and is renowned for its highclass research. Mexican universities have a reputation for excellence in business and management, making their graduates sought after by top world companies. Mexico is a unique country worldwide for its fascinating culture and art.

1 In 2016, Polish exports to Mexico amounted to USD 531.1 million, and imports to USD 536.3 million. This resulted in a small negative balance of $-5.3 \%$, while in 2011-2015 Poland maintained a positive balance with Mexico as the only Latin American country. The share of Mexico in Polish exports amounted to $0.26 \%$, while in import to $0.27 \%$. Poland was the 32nd Mexico's trading partner in the world, while Mexico was for Poland 46th among business partners (GUS' data). 
Table 1. Selected indicators for Poland, Mexico and Chile (2016)

\begin{tabular}{|l|c|c|c|}
\hline Indicator & Poland & Mexico & Chile \\
\hline Population (million) & 38.5 & 120 & 17.8 \\
\hline GDP per capita (US\$) & 27,058 & 18,535 & 22,727 \\
\hline Average wages (US\$) & 25,921 & 15,311 & 28,434 \\
\hline Education spending (US\$ per student) & 9,708 & 8,949 & 6,952 \\
\hline Mathematics performance in PISA (mean score) & 510 & 412 & 432 \\
\hline Reading performance in PISA (mean score) & 491 & 416 & 453 \\
\hline Science performance in PISA (mean score) & 504 & 420 & 454 \\
\hline Youth not in employment, education or training, NEET (\%) & 5.7 & 8.1 & 10.1 \\
\hline Gross domestic spending on R\%D (\% of GDP) & 1.0 & 0.5 & 0.4 \\
\hline Government spending on education (\% of GDP) & 4.9 & 5.3 & 4.9 \\
\hline Internet access (\% of all households) & 81.4 & 47 & 71.6 \\
\hline Triadic patents (indicator) & 100.4 & 19 & 12.6 \\
\hline $\begin{array}{l}\text { Wireless mobile broadband subscriptions } \\
\text { (per 100 inhabitants) }\end{array}$ & 65.3 & 57 & 61.5 \\
\hline
\end{tabular}

Source: https:/ / data.oecd.org/innovation-and-technology.htm

\section{The Mexican higher education system}

Mexico is a federal Republic that covers 32 federal entities: 31 States and one federal district (Distrito Federal, DF) corresponding to the metropolitan area of the federal capital, Mexico City, with each state having its own constitution, congress, and a judiciary. Therefore, Mexico actually numbers 33 educational systems (a federal one and 32 regional ones) at all educational levels, including higher education. The founding principles laid down in the Federal Constitution of 1917 include: the right to free (public) education, the laicism of education and (following an amendment of 1980) the autonomy of public universities. The Constitution also guarantees the "freedom to teach", i.e. the freedom to deliver private education at all levels, within the framework of the applicable legislation.

While over $90 \%$ of children in Mexico attend primary school, only $62 \%$ attend secondary school (secundaria), and only $45 \%$ finish high school (preparatoria). After secondary school, only a quarter pass on to higher education. According to the OECD, in 2015 , only $16 \%$ of adults completed their tertiary education. This is the lowest share across all economically similar countries. ${ }^{2}$ A commonly cited reason for this is the lack of infrastructure throughout the rural schools, poor quality of education at all stages and a low level of investment into the education system. In its annual report on education, the OECD (2016) placed Mexico at below average in

2 The figures are improving, however: $21 \%$ of young people aged 25-34 have a degree compared with just $12 \%$ of 55 - to 64 -year-olds (OECD, 2017). 
mathematics, science, and reading. The results for Poland are definitely better in this respect (see Table 1 ).

At the tertiary level of education in Mexico, the enrolment rate is ca. $33 \%$ for the age group 19-23. With a total enrolment of 3.3 million students in tertiary education (including over 300,000 open/distance education students) spread across more than 5,000 public and private higher education institutions, the Mexican higher education system is the second largest in Latin America after Brazil (ca. 7 million students). It has been growing rapidly at an average rate of about $3.5 \%$ per annum, which is however lower than Brazil and Latin America in general, where higher education has increased by $80 \%$ over the past decade. The total number of teachers in Mexican higher education is estimated at over 315,000 (in Poland 91,000 as of 2016). The level of education of academic teachers is low, of which only a relatively small proportion have doctoral degrees. About 100 new public HEIs have been created annually in each of the past few years in Mexico. The above figures mean that Mexican higher education has become significantly larger than any national system in the EU, both with respect to the total number of students and the annual output of graduates: 420,000 (ECORYS; OECD Science 2017).

Mexican higher education usually follows the US education model with an at least 4-year undergraduate level bachelor's degree (Licenciatura), and two degrees at the postgraduate level, a 2-year Master's degree (Maestría), and a 3-year Doctoral degree (Doctorado), followed by the higher doctorate of Doctor of Sciences (Doctor en Ciencias). This structure of education closely conforms to the Bologna Process started in Europe in 1999, allowing Mexican students to study abroad and pursue a master's degree after Licenciatura, or a Doctoral degree after Maestría. Unlike other OECD countries, the majority of Mexico's public universities do not accredit parttime enrollment programs.

At the federal level higher education falls under the responsibility of two main bodies:

1. The Secretariat of Public Education (Secretario de Educación Pública, SEP) of the Federal Government, dating back to 1921. There are two entities in the SEP relevant to higher education: the Deputy Secretariat for Higher Education (Subsecretaría de Educación Superior, SES) and the Department for Evaluation and Planning (Unidad de Planeación y Evaluación de Políticas Educativas, UPEPE).

2. The National Council for Science and Technology (Consejo Nacional de Ciencias y Tecnología, CONACYT), created in 1970, is responsible for the conducting nation-wide policy in science and technology, and for the development of research capacities and technology transfer to enterprises throughout the country. A new Law on Science and Technology confirming Mexico's ambitions in the Knowledge Society was adopted in 2002, while in 2018 Mexico is working on an amendment of the Law. CONACYT's role is particularly important in the development of research oriented postgraduate studies. As part of this mission, it runs (in cooperation with the SEP) the National Program for the Quality of Postgraduate Studies (Programa Nacional de Postgrados de Calidad, PNPC), a peer-review based evaluation scheme aimed at "labelling" and supporting centers of postgraduate studies of distinguished quality, able to become internationally competitive. As an extension to the evaluation program, the CONACYT maintains a Register of (currently over 1300) postgraduate courses of excellence; $57 \%$ of these are Master 
degrees, 30\% PhD programs and 13\% "Specialization courses". CONACYT also runs an entire series of domestic and international grant schemes for Mexican academic and scientific staff pursuing postgraduate studies, in particular at the doctoral and post-doctoral level. CONACYT emphasizes the importance of international cooperation agreements in higher education and research.

Mexico's large and heterogeneous tertiary education system includes many different categories, networks, associations and clusters of HEIs, depending on their legal status, affiliation, scope, self-image, reputation, etc. Currently, the country has over 3,000 officially registered institutions of higher education, ${ }^{3}$ of which the majority $(60 \%)$ are private - even though the private sector accounts for only about one third of the tertiary level students (ECORYS). A number of Mexican HEIs also run courses at the level of upper secondary education (activity common in Latin America in general). In order to qualify as a "university", higher education institutions need to offer at least 5 degree programs (at Bachelor, Master or PhD level) in at least 3 different areas. As a consequence, only about one third of registered HEIs are "universities" (even though some may not be called Universidad, but for example Instituto Tecnológico). 380 of these are public universities, and some of the best known among them are "autonomous" such as the UNAM; others are "federal" universities (such as the College of Mexico, the National Institute of Anthropology and History, the National Pedagogical University with campuses all over the country or the brand new National Open and Distance Education University), or State universities.

There are many groups and networks of Higher Education Institutions (ECORYS). The most important network of HEIs in Mexico is the National Association of Universities and Higher Education Institutions (Asociación Nacional de Universidades e Instituciones de Educación Superior de la República Mexicana, ANUIES) with a membership of 180 universities and other HEIs that represent, as a rule, most of Mexican high quality public higher education. ANUIES represents over $80 \%$ of Mexican higher education institutions (in respect of student numbers). Although ANUIES also counts a small number of private HEIs as associate members, it mainly represents the public sector, where its requirement for membership are seen as a credible substitute to institutional accreditation. Its membership directory provides a list of (mainly public) Mexican institutions of higher education offering a high proportion of officially recognized programs, as well as a directory of their degrees (licenciaturas) and postgraduate programs. ANUIES has, for decades, been the main discussion partner of governmental policy makers; it has been closely involved in policy shaping and runs a series of specialized networks and scholarship schemes in cooperation with, or on behalf of the Federal Ministry of Education (ECORYS; ANUIES).

The most important network of private higher education institutions is the Federation of Private Mexican Institutions of Higher Education (Federación de Instituciones Mexicanas Particulares de Educación Superior, FIMPES), created in 1982. It currently includes 108 institutions that have passed the organization's own procedure for "institutional" accreditation and represent in total 14\% of Mexican higher education institutions (in terms of students numbers).

3 Since a number of these HEIs operate as multi-campus institutions, some of them with a local seat in each State, the total number of higher education "campuses" in the country exceeds 6,000 . 


\section{Internationalization in Mexican higher education}

The Mexican Federal Government's main priorities, articulated in the series of multiannual National Plans for Education, are currently related to: 1 . coverage, 2. equity, 3. quality, 4. efficiency (relevance) and 5. funding. All these priorities have a bearing on the internationalization of Mexican higher education, which needs to be analyzed as a separate dimension.

Internationalization has been a growing priority in Mexican higher education agendas since the beginning of the 20th century. Nevertheless, Mexican internationalization is following other patterns and priorities to those in Europe and, in particular, in Poland. Mexican-style internationalization affects some issues, rather than the whole of the higher education sector. Some aspects that are high on the Polish agenda for higher education are not seen as core priorities in Mexico.

The internationalization of Mexican higher education has been promoted both by governmental policies as well as the ANUIES. On the governmental side, the SEP's main reason for seeking more internationalization is to improve the quality of the system as a condition for the country's economic and social development, above all at the upper segment of tertiary education and in conjunction with research (ECORYS, SEP). While the number of higher education teachers has tripled in Mexico over the last three decades, the majority of them seriously lack international recognition and experience; this is why the federal government seeks to address this issue through a series of programs ranging from basic language learning to high-quality postgraduate studies abroad for teachers and above all for researchers (mainly through CONACYT programs and grants).

Internationalization has also become an even more strategic item on the agenda of the ANUIES, encouraging its members to engage in various types of internationalization strategies and initiatives: incoming and outgoing student and staff mobility, the internationalization of curricula and course materials, seminars and publications about internationalization strategies and indicators of internationalization, inter-institutional agreements, joint programs, etc. (ANUIES; ECORYS). Historically, the main emphasis of international cooperation and mobility has been with HEIs in the US, as proximity plays a big role in US - Mexico relations (trade, investment, migration issues, etc.), but Europe has always been an important alternative destination. According to the latest ANUIES data international activities of ANUIES member institutions were mainly organized (92\%) on the basis of bilateral (and to a lesser extent trilateral/multilateral) inter-institutional agreements. These activities cover an entire range of disciplines: 23\% were in Education, 23\% in Social Sciences, $20 \%$ in Engineering, 15\% in Natural Sciences, 13\% in Health et al. Students and academic staff going abroad went mainly to Europe $(46 \%$, with a strong focus on a limited number of countries), the USA (33\%) and Latin America (17\%). Visiting students/ staff came mainly from the US (37\%), Europe (34\%) and Latin America (15\%). Mexican higher education institutions actively participate in the EU's mobility programs with third countries, such as Erasmus Mundus or MarieCurie.

Another major player in mobility and cooperation in Mexican higher education is the Mexican Association for International Education (Asociación Mexicana para la Educación Internacional, AMPEI). The AMPEI has a membership of about 150 academic and professional experts (belonging to some 50 different HEIs) directly involved in 
international higher education. ${ }^{4}$ It organizes conferences, workshops and seminars and issues publications aimed at developing international awareness and capacities at member institutions. The institution maintains relations with its sister associations in Europe (the European Association for International Education, EAIE) (ECORYS). The AMPEI will need to be a key player in the further internationalization of Mexico's higher education and its stronger cooperation/mobility with Poland.

\section{The tradition of Polish-Mexican academic cooperation}

Collaboration between Polish and Mexican universities has a long tradition, but its intensive development took place gradually, first after 1990 (to a limited extent), and then, to a greater extent, from the first decade of the 21st century. In previous decades, mutual relations were based primarily on spontaneous contacts between scientists whose acquaintance, established during the conference, continued in the form of ad hoc cooperation on common publications, scientific projects, joint seminars and workshops. Many valuable initiatives were created, and some Polish universities managed to gain recognition and a high reputation in numerous Mexican centers, and vice versa. These activities resulted in several common projects and research initiatives, some of them lasting until today.

Many years of positive experience of cooperation between Polish and Mexican universities prompts building even stronger institutional links between the countries. At the moment, mutual relations need to be systematized according to the internationalization schemes followed by both countries. In order to meet expectations and needs, the authorities of many Polish universities have consistently encouraged the building of formal relations with Mexican universities, involving various universities units, using tools available to facilitate and to target in the desired direction.

\section{Formal and legal framework of Polish-Mexican academic cooperation}

Polish-Mexican scientific contacts follow traditional schemes of cooperation between the two countries. One of the most important examples of cooperation has been cooperation in the field of art universities. Between 1970-1990, Poles undertook intense didactic work in Mexican art schools in the capital of the country and in Xalapa. Polish poster designers have contributed to the development of an active environment of Mexican graphic and poster designers, which was later called "the Polish school". Young Mexicans also studied photography, art design, film direction, singing, graphics and other fields of art at a number of Polish universities (Rycerz 60).

Following the political transformation in Poland, a new formal and legal framework of cooperation was needed. There was the "Agreement on cooperation in science and technology between the Government of the Republic of Poland and the

\footnotetext{
4 Contrary to similar organizations in other Latin American countries (e.g. Brazil, Argentina, Chile, etc.), the AMPEI is an independent membership organisation, not a Commission or a dependency of the National Rectors' Conference.
} 
Government of the United Mexican States for the development of scientific cooperation", signed on the occasion of Polish Prime Minister Jerzy Buzek's visit to Mexico in November 1998 (operating since March 2000) of great importance for further relations. It concerned, in first order, cooperation in the field of joint scientific and research projects, exchange of scientists, documentation and information, as well as organization and participation in international conferences. The Joint Commission for cooperation in science and technology, established under this agreement, was to develop executive programs (Osuchowska 85-86).

On the other hand, in parallel to intergovernmental agreements, cooperation between universities has been developing. Several contacts between individual research centers and research groups enjoy a long tradition, with numerous scientific outcomes.

The openness of Polish universities to cooperation with Mexican universities and plans to sign the CRASP-ANUIES agreement were already being discussed with the Mexican government during the 10th Polish-Mexican Political and Economic Consultations held in parallel on November 10-11, 2016, in which a large Polish delegation participated, with the presence of the Undersecretary of State of the Ministry of Foreign Affairs. Plans to intensify Polish-Mexican academic cooperation were very positively received by both sides and are considered one of the most important pillars of bilateral relations.

The intensification of scientific cooperation between countries is to be facilitated by the signing of a Cooperation Agreement between the Conference of Rectors of Academic Schools of Poland (CRASP) and the ANUIES on January 31, 2018. Mexican rectors and representatives of the Mexican authorities received proposals to strengthen relations with Polish universities with great interest. In order to institutionally integrate Polish universities into scholarship programs in Latin America, a coordinated campaign is needed, which is already being developed if the efforts put in by the CRASP to establish cooperation with similar conferences in Latin American countries are taken into account. The CRASP-ANUIES agreement is one of the most important steps forward to closer academic cooperation between the countries.

As further steps ahead, special agreement on cooperation between AMEXID and AMPEI with Polish counterparts will be required in the further way of cooperation, as well as intergovernmental agreement on the recognition of diplomas.

Poland and Mexico also cooperate in the technical and scientific area, which is regulated by the 1998 Agreement on Scientific and Technical Cooperation. Until 2017, however, no Mixed Commission was established to deal with this area of cooperation. Cooperation in this area is developed independently between universities and scientific units. Importantly, the AMEXID identified sectors in which the intensification of cooperation is possible, among which the following are of particular importance: the natural environment, agriculture, health care, water and sanitation technologies, energy, science and technology, and tourism (Recomendaciones... 51). ${ }^{5}$

5 The authors of the document "Recommendations for strengthening relations between Poland and Mexico" (Recomendaciones para el fortalecimiento de la relación entre México y Polonia) have analyzed potential areas of joint academic and scientific activities. They are mainly: education, music education, language learning and diplomas, indigenous languages and 
Due to the great interest in learning Spanish in Poland, it is advisable to promote the study of this language and its certification by the UNAM and the Cervantes Institute. Additionally, a good step towards promoting Polish language and literature in Mexico would be to introduce appropriate classes at one of the Mexican universities and establishing a research and educational Polish center in Mexico, which could be a Polish hub in Latin America, bringing together students and scientists interested in Polish culture, language, art, economy and politics.

\section{Agreements between universities}

On the occasion of a visit to Mexico in September 2016, Prof. Marcin Pałys, the rector of the University of Warsaw, renewed the agreement with the largest and most important Mexican university, UNAM, enabling student and research exchange between both universities. The agreement will be valid for the next five years and will enable the implementation of joint scientific projects, conferences, symposia and online educational programs ${ }^{6}$. It is worth mentioning that at the same university (UNAM) in November 2016, the 200th anniversary of the University of Warsaw was organized, during which an exhibition: "University of Warsaw. Two centuries. Good beginning" was presented. . Thanks to the exhibition, UNAM's students and academics could have a closer look at the biggest Polish university in the 200th anniversary of its existence and learn about possibilities to study and conduct research projects in Poland.

At the moment, the University of Warsaw has signed agreements with 16 Mexican universities and research institutions, usually facilitating the exchange of students, doctoral students and researchers as well as joint research projects. In addition to the UNAM, the list of partners include: University of Guadalajara, Autonomous University of Zacatecas, University of Monterrey, Autonomous University of Sinaloa, Instituto de Docencia e Investigation Etnológica de Zacatecas, Autonomous University of Sinaloa, El Colegio Mexiquense, A.C., University of Anahuac, El Colegio de México, Instituto Technológico y de Estudios Superiores de Monterrey, Fundation Universidad de las Americas Puebla, Centro de Investigation y Docencia Economicas CIDE, Instituto Tecnológico y de Estudios Superiores de Occidente, Autonomous Metropolitan University and University of Guanajuato. ${ }^{8}$ As another example, the memorandum on cooperation between the University of Warsaw and the AMEXCID was signed in July 2016, under which the Cathedral of Mexico (Cátedra México) was established at the University of Warsaw, under the care of the Institute

scientific cooperation within the EU. For Mexico, it would be valuable to take advantage of the experience of Polish reforms in the education system.

6 On the occasion of the ceremony of signing the agreement, Ambassador Beata Wojna proposed the organization of a series of joint conferences devoted to economic and cultural exchange between the two countries and possible cooperation with Polish academic institutions that offer educational programs in English (Meksyk i Polska podpisuja...).

7 https://uw200.uw.edu.pl/pl/dwa-stulecia-dobry-poczatek/ [accessed on: 15 January 2018].

8 http://en.uw.edu.pl/cooperation/higher-education-cooperation/ [accessed on: 15 January 2018]. 
of Iberian and Ibero-American Studies. The agreement allows Mexican researchers to participate in the University of Warsaw scientific and didactic activities as "visiting professors", in particular in cooperation with the Faculty of Neofilology and the Biological and Chemical Research Center.

Several cooperation agreements are been negotiated and firmed successfully between other Polish and Mexican universities, institutes, and colleges. The Jagiellonian University has signed agreements with two Mexican universities: Mexico City College in 2010 and UNAM in 2017. ${ }^{9}$ The interest of the Jagiellonian University in Latin America and, in particular, in Mexico enjoys a long tradition. The special role is played by the Institute of American Studies and Polish Diaspora, established in 2004. The Institute is a multidisciplinary unit, employing historians, sociologists, experts in political science and literary scholars. The primary objective of this institute is to conduct research in the field of: American, Polish Diaspora, Ethnic, and Latin American studies. The Institute also runs educational activities by offering undergraduate (BA) and graduate (MA) studies in several different specialties. In 2018, it began offering curricula in Latin American Studies (UJ). Other Polish university centers are also very active in the area of Latin American studies, in particular in the Maria Curie Skłodowska University in Lublin (UMCS) and the University of Lodz.

The AGH University of Science and Technology carries out Cooperation Agreements with six Mexican universities, while the Wrocław University of Science and Technology cooperates with three Mexican partners. Subsequent agreements, e.g.: Cooperation Agreement between the Music University of Fryderyk Chopin in Warsaw and the National Institute of Fine Arts (Instituto Nacional de Bellas Artes, INBA) are currently under negotiation. An update of the Bilateral Agreement on cooperation in the field of tourism and the Cooperation Agreement in the field of physical culture and sport, between the Ministry of Sport and Tourism of the Republic of Poland and the Mexican Commission on Physical Culture and Sport (CONADE) is also being prepared (Recomendaciones... 52).

There are institutes of Iberian studies at several Polish universities, also offering courses on Latin American culture and history. In March 2018, on the occasion of the visit of Prof. Enrique Graue, the UNAM's rector in Warsaw, "Mexican corners" were inaugurated in the libraries of the University of Warsaw and the Jagiellonian University. Polish students and scientists gained on-line access to the UNAM's digital resources: podcasts, movies, radio programs, literary documents and scientific literature.

\section{Scholarships}

The Mexican Directorate-General for Educational and Cultural Cooperation, designs and manages the Ministry of Foreign Affairs' Scholarship Program for Foreigners. The scholarships of the Mexican Government present two programs: the scholarship for academic studies and the scholarship for special programs. The scholarships for academic studies are offered to complete programs for a specialization, master's or PhD degrees, and postgraduate research. Mexico offers Polish students seven such annual scholarships. Likewise, the offer includes academic mobility for bachelor's

9 http://www.dwm.uj.edu.pl/en_GB/pracownicy/lista-umow-miedzyuczelnianych [accessed on: 20 January 2018]. 
and postgraduate degrees. On the other hand, the scholarships for special programs are offered to complete short-term fellowships addressed to Visiting Professors, research on issues pertaining to Mexico, media contributors, art production fellowships, etc.

Poland also offers seven scholarships to Mexican students to complete academic internships in public higher education institutions. Completing master's as well as PhD studies in Polish or English is also possible. Between 2011-2016, as many as 81 Polish students benefited from government scholarships, while there were only 19 people from the Mexican side. The reasons for a small number of the Mexicans choosing to study in Poland are, according to the Mexican government (Recomendaciones... 49-50): language barriers (the Polish universities offers learning programs only in English, which limits the number of Mexicans interested in these curricula) and financial barriers (scholarships offered by the Polish government are almost three times lower than those offered by other countries to Mexico or by institutions in the country, e.g. CONACYT). It is worth noting, however, that the scholarships of the Polish government are offered under the same conditions to students from all countries, and - what is significant - Mexico is the only country in Latin America to be granted scholarships for students under this scholarship agreement (GocłowskaBolek, Programy stypendialne... 135).

Due to the possibility of widespread dissemination of scientific achievements, that greater freedom of mobility of students and researchers, and access to foreign education opportunities, fulfilling "a national science and higher education function in global competitive conditions in the area of scientific discoveries and talents", the Polish Ministry of Science and Higher Education established the Polish National Agency for Academic Exchange (NAWA). NAWA forms a part of the system for supporting the development of Polish universities and research units, in cooperation with the government administration (in particular with the Ministry of Foreign Affairs, the Ministry of Finance and the Ministry of Development), the National Science Centre (NCN), the National Centre for Research and Development (NCBR), the Foundation for Polish Science (FNP), the National Contact Point for Research Programs of the EU, the Foundation for the Development of the Education System and with other entities that contribute to internationalize Polish higher education. The aims of NAWA include promoting Poland as a country offering interesting educational and research opportunities and promoting the Polish language and culture. ${ }^{10}$ This institution, which has funds for scholarships for foreign students, PhD students and scientists, can help boost academic cooperation with Mexico.

\section{Mexican students in Poland}

Currently, there are about 65.7 thousand international students in Poland, from 158 countries. This is undoubtedly a reason for satisfaction, especially when taking into account that in 2000, there were only 6.5 thousand foreign students in Poland. Poland is, apart from Croatia, the least internationalized country in the European Union and one of the least internationalized in the OECD. An unfavorable phenomenon is also the poor diversification of the foreign students' directions of origin in

10 https://nawa.gov.pl/en/nawa [accessed on: 10 January 2018]. 
Poland. Over half (54\%) of the foreign students come from Ukraine. Subsequently, foreign students come to Poland from: Belarus 7.8\%, India 3.3\%, Spain 2.4\%, Norway $2.3 \%$, Sweden $2 \%$, Turkey $1.9 \%$, Germany 1.8\%, Czech Republic $1.6 \%$, Russia $1.6 \%$, China $1.5 \%$, Saudi Arabia 1.3\%, Lithuania 1.2\%, US 1.2\% and Taiwan $1.2 \%$ (Edukacja). And although Latin America enjoys a growing interest of Polish students and scientists and Poland is appreciated in Latin America, due to the growing role and position in the global economy and international relations, as well as the rich, fascinating culture, the statistics of exchange students leave no place for illusions. In 2017 only 266 students from Latin America came to Poland (in 2012 there were 155, while in 2005 only 55). ${ }^{11}$

The majority of Mexican students come to the University of Warsaw, in the years 2013-2017 there were 119 of them in total. In 2017, there were 66 Mexican students at the same university, at various levels of study. Mexicans are the 12th most numerous group of international students at the University of Warsaw.

Figure 1. International students from the US, Canada and Latin America in Poland 2004-2016

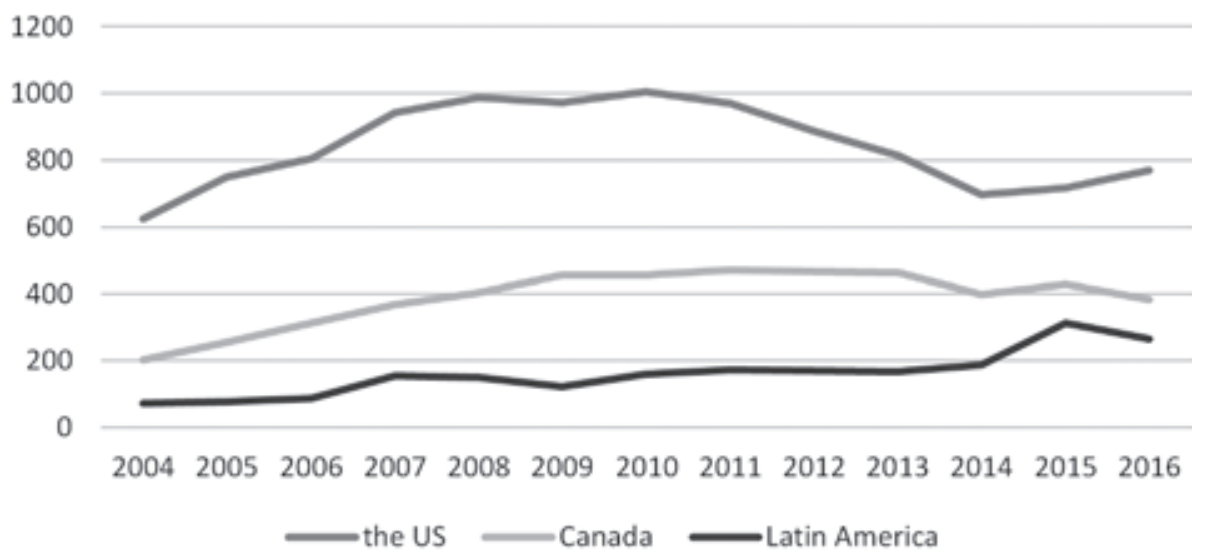

Source: Own study on the basis of GUS data (various years).

Meanwhile, one cannot overestimate the importance of diversifying the directions of origin of students and academic staff, if the aim is to create a wider platform for education and research, a real exchange of scientific ideas with different regions and building multi-faceted relationships with various universities around the world. It is worth considering assigning in the strategies of internationalization (both on the level of a university and in general) a priority importance to the countries of the Latin American region. Latin America is now facing similar challenges, but in the absence of adequate scientific and research infrastructure - which will take many years to build - is being forced to search for strategic partners (UNESCO 29). Such partners can be successfully found in Poland.

\footnotetext{
11 An interesting example here can be the University of Warsaw, one of the most internationalized in Poland, where 1,630 foreign students study at full-time (undergraduate, graduate and doctoral level) and 1,622 at part-time studies. Of these foreign students, only 66 come from Latin America - including 12 from Brazil and 35 from Mexico.
} 
Figure 2. International students from Latin America in Poland 2004-2016

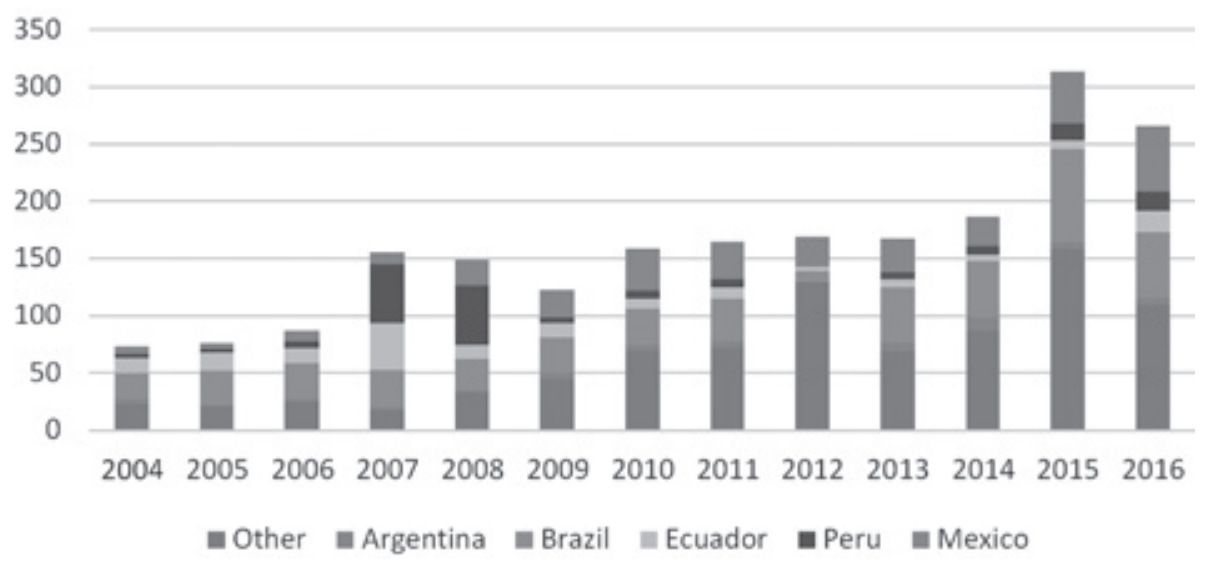

Source: Own study on the basis of GUS data (various years).

\section{Joint research projects}

Polish and Mexican universities and research institutes carry out a number of joint R\&D projects. Collaboration with the largest Mexican universities is explored by many Polish universities, including: the University of Warsaw, the AGH University of Science and Technology in Krakow, the Wrocław University of Science and Technology (collaborating mainly with the National Polytechnical Institute in Mexico), or the Fryderyk Chopin University of Music (collaborating with the National Institute of Fine Arts - Instituto Nacional de Bellas Artes, INBA), the University of Lodz, Jagiellonian University, or the University of Silesia in Katowice ${ }^{12}$. Activities supporting the development of scientific cooperation are also undertaken by the respective Embassies in both countries. One example is a lecture on "Solidarity" and its role in the democratic transformations in Poland and Central Europe for students of the international relations faculty at the University of Technology in Monterrey (ITESM, campus in Mexico City), organized by the Polish Embassy in Mexico in October 2016 (Fenomen „Solidarności”...). At the same time, the Mexican Embassy in Warsaw has been running an educational and scientific project since 2016, in cooperation with scientists from the UNAM, offering a series of on-line and live lectures delivered by the best Mexican scientists, dealing with Mexico's culture, literature and history.

One of the most important scientific projects is the revitalization of the Nahuatl language, which the University of Warsaw is carrying out in cooperation with the Ethnological Academic and Research Institute in Zacatecas. The idea covers Mesoamerican ethnohistory, anthropology, Nahuatl ethnolinguistics, and the

12 The Faculty of Philology at the University of Silesia in Katowice carries out semantic, cultural and sociolinguistic research on the influence of indigenous American Indian languages on Spanish. 
revitalization of endangered languages. The research project deals with cross-cultural transfers between Europe and the New World taking written sources produced by members of the native nobility in central Mexico as the case study. The special focus is the Nahuas, one of the most important culture groups of Mesoamerica, who primarily occupied the area of central Mexico. Such an approach, innovative within the discipline, is very promising for an attempt to identify and reconstruct similar phenomena in two different regions, both of them of primary importance for the expansion of European culture in the Americas. This study is conceived as an experiment that crosses the narrow borders of the discipline involved (Latin American ethnohistory), where regional studies are dominant. Since 2012, an international interdisciplinary project within the ERC Starting Grant has been run at the University of Warsaw by Dr. Justyna Olko's scientific team in cooperation with Mexican partners. The project: "Europe and America in Contact: A Multidisciplinary Study of the Cross-Cultural Transfer in the New World Across Time" is to reconstruct the mechanisms of cultural communication between Europe and America from the 16th century through the colonial period to the present day. The international research group focuses on the changes taking place in the language and culture of the Nahua Indians (commonly known as the Aztecs) that is still alive today. The group also analyzes the transformation of the Spanish language under the influence of Indian languages and cultures. It is worth noting that the University of Warsaw is the only university in Europe which offers regular Nahuatl courses in its historical and contemporary versions. Other Polish universities are also beginning to develop cooperation that aims, among others, at developing the growing interest in Poland in the culture and heritage of Mexico, including autochthonous languages or archaeological excavations.

Poland is recognized in Mexico as a leader in music education and research. The Mexican side is interested in allowing Mexican students to complete postgraduate studies at Polish conservatories. There is promising cooperation in the field of music developing between the Fryderyk Chopin University of Music in Warsaw and the National Institute of Fine Arts (INBA), and the Mexican National Conservatory of Music, aimed at establishing a program of student and scientific exchange (Recomendaciones... 50).

Scientific units of Polish and Mexican institutions can participate in the EU funding programs for research and development, Horizon 2020. Being an EU Member State, Poland may participate in a number of other EU initiatives resulting in strengthening scientific relations with countries in the region, including Mexico, such as the Erasmus Mundus program or the Mexico Bilateral Innovation Initiative (EU-MEX-INNOVA). EU-MEX-INNOVA is an initiative aimed at developing cooperation in several areas: climate change, food security, sustainable development, clean energy, health and transport, science and research, or innovation. Poland also cooperates with Mexico through the EU Alfa Puentes program, which allows to strengthen the Latin American and EU higher education area by creating effective mechanisms for modernization, reform and the harmonization of education systems in Latin America and Europe ${ }^{13}$.

13 http://alfapuentes.org/portal, [accessed on: 10 January 2018]. 


\section{Main challenges in developing academic cooperation}

The main challenges in the development of internationalization in general, and for Mexican-Polish cooperation and mobility in particular, are related to a series of structural as well as academic factors in Mexican and Polish higher education:

- Funding difficulties ${ }^{14}$, in both countries.

- One of the main challenges is language. A limited number of students and teachers are prepared to study and work in English, although the knowledge of English is becoming increasingly common among the younger generation. In Mexico, $12.9 \%$ of the adult population claims to speak English, which represents 9.5 million Mexicans over the age of 18 with access to that language. Of these, only $12 \%$ claims to read English perfectly and 9\% claims to speak it with quality, which is equivalent to approximately 850,000 people. Poland achieved a high level of proficiency in English, ranked 11th in the EF English Proficiency Index score of 62.7 versus Mexico being the 44th in the ranking with the score of 51.57 (EF EPI). ${ }^{15}$

- A limited number of programs in English at all levels of study, in both countries.

- A low number of students enrolled at the postgraduate level (only about 7\%), in particular at the PhD level $(0.2 \%)$; this makes Mexican higher education less attractive for research universities in Poland, keen to find good partners for the exchange of researchers and students at the postgraduate and doctoral levels.

- Weaknesses of the scientific, didactic and administrative staff in Mexico at HEIs: many Mexican academics are not fully qualified, not well paid and work only parttime as they need to do extra classes (only 81,000 of the 330,000 higher education teachers have full-time contracts); only a small minority of them are involved in research activities and an even smaller minority (16,000, i.e. less than 5\%) belong to the National Research System; there are not enough professionals involved in the management of international cooperation and mobility (with some exceptions).

- Security issues, which act as a deterrent for many Polish students, researchers and institutions that might otherwise choose Mexico as their destination. Many Mexican universities have had problems with regional crime and violence. Drug-related crime, rising unemployment and low salaries are all contributing to a postgraduate shortage that indicates an uncertain future for Mexico's higher education system (Pells). On the other hand Poland may be seen as a stable, secure destination for the Mexicans.

- Braindrain issues play a role in this cooperation scheme between Mexico and Poland, but they are not seen as a major determinant in the shaping of mobility

14 Major economic encouraged the Mexican government to double the spending on research and development in the past 20 years, but at 0.55 per cent of GDP, the sums are still small by global standards (Pells). The OECD describes Mexico as having "one of the lowest scientific and innovation outcomes as measured by number of scientific publications and triadic patents per GDP", with "very few" patents filed by universities and public research institutions between 2005 and 2009 (OECD, 2017).

15 Latin American countries classified in the EF EPI 2017 ranking: category "moderate": Argentina (25th), Dominican Republic (26th), Costa Rica (35th); category "low": Brazil (41st), Uruguay (43rd), Mexico (44th), Chile (45th) Cuba (48th), Panama (49th), Peru (50th), Colombia (51st), Guatemala (54th), Ecuador (55th); category "very low": Venezuela (68th), El Salvador (69th); (EF EPI). 
patterns; the two countries do not tend to see each other as a threat in this aspect (Gácel Ávila 402; Pells 2). According to OECD findings (2017), scientist mobility facilitates the circulation of scientific knowledge. One way to track the mobility of scientists is to trace changes in institutional affiliation over their list of publications in scholarly journals. This approach shows that brain circulation (churn) is far more important than brain gain/drain (net flows). In this category Poland scores the least out of 41 countries investigated by OECD. Only $1.17 \%$ of scientific authors are classified as "returnees" in Poland, while the net inflow accounts for $1.03 \%$ of authors. figures for Mexico: $2.17 \%$ and $3.36 \%$, respectively are significantly higher, though still below the OECD average (OECD Science...).

- Mexican higher education has focused mainly on responding to a fast growing internal demand and only recently started to work on its international competitiveness (similar phenomenon, to smaller extent, could have been observed in the case of Poland). In spite of complicated procedures for the recognition of foreign studies, international mobility has benefited a significant number of students and staff, but it has not (yet) produced an impact on institutional strategies, structures and attitudes in both countries.

- Many Polish HEIs and individuals still view Mexico as a less-developed country and fail to recognize that the system offers a significant number of high-quality universities, competitive study programs, high-level research teams and excellent students at the undergraduate, master and $\mathrm{PhD}$ level.

- Many Mexican students have difficulties in fulfilling the requirements for study abroad, either because their studies are not up to the expected standards (a reality that tends to be related to financial, social and cultural factors), their proficiency in foreign languages is insufficient, their inability to afford the related travel and study costs or their unavailability because they study part-time and have a job on the side (ECORYS). However, Mexican higher education also numbers a significant proportion of students and graduates who are very well prepared, especially those studying highly demanding programs (engineering, natural sciences, computer science, and other) at reputable - mainly public - institutions; either on the basis of their own resources or due to Mexican or international grants, many of these students wish to continue their postgraduate studies abroad at prestigious international institutions - mostly in the US and in Europe.

- Both Mexican and Polish scholars often find it difficult to leave their posts for longer periods of time as they may lose their position at the University (or due to family commitments). The solution favored by universities would be a one-toone exchange, where a Polish academic takes the place of a Mexican academic for a predetermined period of time.

- Low level of knowledge about both countries among their societies.

\section{Conclusion}

Internationalization provides for the exchange of knowledge, experience and discoveries, allows to use the research potential of scientists and infrastructure in a multidimensional way, and contributes to a better quality of research and didactics. Increasing internationalization breaks down societal and cultural barriers and builds 
up international economic competitiveness (Espinoza 57). Its effects are significant in many aspects. Latin America, especially Mexico, is a prospective and attractive region, strongly developing and investing heavily in science and higher education. In Mexico, the increasingly richer middle class is systematically growing in number, among which the social awareness of the value of higher education diploma in Europe is enormous, and the opportunities for cooperation, including the scientific one, seem to be interesting and beneficial for both countries (Gocłowska-Bolek, Fostering Economic... 202).

Although the main partner of Mexican internationalization has always been the US, there is a clear awareness at all levels that Mexican teachers and students also need to know Poland for cultural, economic and political reasons. For many Mexican universities, Polish partners might be strategic partners in the process of internationalization, with mutual benefits and promising outcomes. Due to low cost of living, attractive location and a relatively good reputation in terms of the level of education, Poland can attract many Mexican students and researchers who want to continue their career learning about other directions than those traditionally exploited and already recognized. Poland is perceived by Mexicans as a calm and friendly country, which in the situation of turmoil in the international environment, especially in relations with the northern neighbor, may be of great importance for the further course of academic mobility. And vice versa, Mexico may be an increasingly attractive partner not only due to rich culture, dynamic economic and social development, as well as growing economic and business potential, but also due to the relatively high level of research in selected fields and additional funding for research in priority areas that they may be of common interest to international research groups.

For several years, intensive activities of individual universities, governmental institutions and the CRASP have been carried out, aimed at building academic and scientific relations also with the Latin American region, especially with Mexico. However, for a significant increase of interest in the Polish educational offer and scientific cooperation, a complex, well-planned promotion of the educational and research offers and opportunities, as well as national brand promotion in general is needed. An informational and promotional campaign of Polish universities with the support of government institutions and "university brand marketing" is required, which would allow Polish universities with their specializations or university brands to br distinguished from other universities in the world. The CRASP-ANUIES agreement signed in January 2018, which is to create the basis for institutional cooperation and facilitate many subsequent initiatives, can be of great importance in this sense. It may be helpful to develop relationships with the Polish Diaspora and with the Mexican diaspora in Poland.

It may be important to use the scholarship programs offered by the governments of both countries, including the opportunities created by Mexican CONACYT and the National Agency for Academic Exchange (NAWA) recently established in Poland. There are already various scholarship programs that can be successfully used by students and academics from Poland and Mexico, but a broader offer is needed. Several activities are undertaken to improve cooperation, such as joint research projects carried out by scientific units in both countries, the participation of scientists and experts from Poland and Mexico in science, technology and innovation events, and an increase of student and academics exchange. It will be important to sign a specific agreement with the AMEXID and AMPEI, and a diploma recognition agreement to foster cooperation. 
In the field of Polish-Mexican scientific cooperation, there are many convergent interests and areas of common interest. But the main challenge is still finding financial resources for the development of Polish-Mexican academic cooperation.

\section{References}

Altbach, Philip G., and Knight, Jane. “The Internationalization of Higher Education: Motivations and Realities." Journal of Studies in International Education, 11, 3-4, 2007: 290-305, https:/ / doi.org/10.1177/1028315307303542.

Blumenthal, Peggy, et al. Academic Mobility in a Changing World: Regional and Global Trends. London-Bristol: J. Kingsley Publishers, 1996.

De Wit, Hans. Internationalization of Higher Education in the United States of America and Europe: A Historical, Comparative and Conceptual Analysis. Westport, CT: Greenwood, 2002.

Dembicz, Andrzej. “Współpraca naukowa między Polską i Argentyną". Relacje ArgentynaPolska. Historia i wspótczesność, edited by Andrzej Dembicz. Warszawa: CESLA University of Warsaw, 1996.

Epinoza, Oscar. "Breaking Down Societal Barriers: Increasing Access and Equity to Higher Education in Latin America." Latin America's New Knowledge Economy, edited by Jorge Balán. New York: The Institute of International Education, 2013.

Gácel Ávila, Jocelyne. “The Process on Internationalization at Latin American HEIs.” Journal of Studies in International Education , 11, 2007: 400-409.

Gocłowska-Bolek, Joanna. "Fostering Economic and Social Innovativeness to Address Development Challenges in Latin America." Openness, Innovation, Efficiency and Democratization as Preconditions for Economic Development, edited by C. Pintilescu, B. Wierzbiński, and G. Zarotiadis. Cracow: Foundation of Cracow University of Economics, 2015: 201-209.

Gocłowska-Bolek, Joanna. "Programy stypendialne w krajach Ameryki Łacińskiej - szansa na skuteczną internacjonalizację polskich uczelni." Czas internacjonalizacji. Wyzwania dla polskich uczelni, edited by Bianka Siwińska, and Marek Zimnak. Warszawa: Dom Wydawniczy Elipsa, 2016: 135-145.

Gocłowska-Bolek, Joanna. “Uczelnie latynoamerykańskie - atrakcyjni i wymagający partnerzy polskiej internacjonalizacji." Czas internacjonalizacji II. Perspektywy, priorytety, projekty, edited by Bianka Siwińska, and Grzegorz Mazurek. Warszawa: Dom Wydawniczy Elipsa, 2017: 218-229.

Johnston, Joseph S. Jr., and Edelstein, Richard J. Beyond Borders: Profiles in International Education. Washington, D.C.: Association of American Colleges, 1993.

Khorsandi Taskoh, Ali. A Critical Policy Analysis of Internationalization in Postsecondary Education: An Ontario Case Study. Ontario: Western University, 2014.

King, Roger. Governing Universities Globally: Organizations, Regulation and Rankings. Cheltenham: Edward Elgar Publishing, 2009.

Knight, Jane. "Internationalization Remodeled: Definition, Approaches, and Rationales." Journal of Studies in International Education, 8 (1), 2004: 5-31, https://doi. org/10.1177/1028315303260832.

Knight, Jane. "Updating the Definition of Internationalization." International Higher Education, 33, 2003: 2-3, https:/ / doi.org/10.6017/ihe.2003.33.7391.

"Low Performing Students: Why They Fall Behind and How to Help Them Succeed." PISA. Paris: OECD Publishing, 2016, http:/ / dx.doi.org/10.1787/9789264250246-en.

Quality and Internationalization in Higher Education, edited by Jane Knight, and Hans De Wit. Paris: Organization for Economic Cooperation \& Development, 1999, http://dx.doi. org/10.1787/9789264173361-en. 
Osuchowska, Zuzanna M. “Kierunki rozwoju współpracy kulturalnej i naukowej”. PolskaAmeryka Łacinska. Historia - polityka - gospodarka - kultura, edited by Michał Drgas, Jacek Knopek, and Anna Ratke-Majewska. Torun: Dom Wydawniczy Duet, 2014: 85-95.

Pells, Rachael. "Mexico's Brain Drain Leaves Universities Struggling to Fill Research Posts". Times Higher Education THE, 3 May 2018.

Qiang, Zha. "Internationalization of Higher Education: Towards a Conceptual Framework". Policy Futures in Education, 1, 2, 2003: 248-260.

Recomendaciones para el fortalecimiento de la relación entre México y Polonia. Zalecenia dotyczące wzmocnienia relacji między Polska a Meksykiem. Warsaw-Ciudad de Mexico: Ministry of Foreign Affairs, 2016.

Rycerz, Danuta. "Polsko-meksykańskie związki w dziedzinie kultury". Relacje Polska-Meksyk. Historia i wspótczesność, edited by Fernando Villagómez Porras. Warszawa: Uniwersytet Warszawski, 2007.

UNESCO. Science Report. Towards 2030. Paris: UNESCO, 2015.

Van der Wende, Marijk. Opening Up: Higher Education Systems in Global Perspective. London: Centre for Global Higher Education, 2017.

\section{Internet sources:}

Alfa Puentes.org. Web. 10 January 2018. http://alfapuentes.org/portal.

ANUIES Asociación Nacional de Universidades e Instituciones de Educación Superior. Web. 10 January 2018. https://anuies.mx/.

Dziat Wspótpracy Międzynarodowej Uniwersytet Jagielloński. Web. 20 January 2018. http:/ / www. dwm.uj.edu.pl/en_GB/pracownicy/lista-umow-miedzyuczelnianych.

ECORYS, "Comparative Study between the EU and Mexico on the Challenges Brought about by the Internationalization of Higher Education and the Transparency Tools Developed on Both Sides to Facilitate Mobility and Academic Cooperation," 30 September 2012, EAC/C.4/JC/DL. Web. 20 May 2018. http://ec.europa.eu/dgs/education_culture/ repository/education/library/study/2012/eu-mexico-report_en.pdf.

EF EPI English Proficiency Index. Web. 20 May 2018. https://www.ef.pl/epi/compare/ regions $/ \mathrm{pl} / \mathrm{mx} /$.

"Edukacja." Główny Urząd Statystyczny. Web. 12 December 2017. http://stat.gov.pl/ obszary-tematyczne/edukacja/.

NAWA Narodowa Agencja Wymiany Akademickiej. Web. 10 January 2018. https://nawa.gov. $\mathrm{pl} / \mathrm{en} /$ nawa.

„Dwa stulecia. Dobry początek.” Uniwersytet Warszawski. Web. 15 January 2018. https:// uw200.uw.edu.pl/pl/dwa-stulecia-dobry-poczatek/.

OECD Science, Technology and Industry Scoreboard 2017. Web. http://www.oecd.org/sti/ scoreboard.htm.

"Fenomen „Solidarności” budzi żywe zainteresowanie meksykańskich studentów." Polish Embassy in Mexico, 11 October 2016. Web. 10 January 2018.

http://www.meksyk.msz.gov.pl/pl/aktualnosci/fenomen_solidarnosci_budzi_zywe_ zainteresowanie_meksykanskich_studentow.

"Meksyk i Polska podpisują umowę o wymianie studenckiej i badawczej." Polish Embassy in Mexico, 14 September 2016. Web. 10 January 2018. http://www.meksyk.msz.gov.pl/pl/ aktualnosci/meksyk_i_polska_podpisuja_umowe_o_wymianie_studenckiej_i_badawczej_.

Politechnika Wrocławska. Web. http://dsm.pwr.edu.pl/en/.

Uniwersytet Jagielloński, Instytut Amerykanistyki i Studiów Polonijnych. Web. 25 April 2018. http://www.iaisp.uj.edu.pl/.

Uniwersytet Warszawski, Biuro Wspótpracy z Zagranica. Web. 25 April 2018. http:/ / en.uw.edu. $\mathrm{pl} /$ cooperation/higher-education-cooperation/. 